Article

\title{
Gypsum and Legume Residue as a Strategy to Improve Soil Conditions in Sustainability of Agrosystems of the Humid Tropics
}

\author{
Emanoel Gomes de Moura ${ }^{1, *}$, Stefanny Barros Portela ${ }^{1}$, Vinicius Ribamar Alencar Macedo ${ }^{2}$, \\ Virley Gardeny Lima Sena ${ }^{3}$, Carlos Cesar Martin Sousa ${ }^{1}$ and Alana das Chagas Ferreira Aguiar ${ }^{4}$ \\ 1 Programa de Pós-Graduação em Agroecologia, Universidade Estadual do Maranhão, Caixa Postal 3004, \\ São Luís 65000-000, Brazil; stefannyportela@hotmail.com (S.B.P.); cc.martins10@yahoo.com.br (C.C.M.S.) \\ 2 Instituto Federal de Educação, Ciência e Tecnologia do Piauí, Campus Uruçuí-Rodovia PI 247, Km 7, S/N, \\ Portal do Cerrado, Uruçuí 64860-000, Brazil; viniram@hotmail.com \\ 3 Universidade Estadual Paulista “Júlio de Mesquita Filho”, Programa de Pós-Graduação em Agronomia, \\ Botucatu, São Paulo 18.610-307, Brazil; virleysena@gmail.com \\ 4 Universidade Federal do Maranhão, Departamento de Biologia, Avenida dos Portugueses, 1966, \\ São Luís 65080-805, Brazil; alana.aguiar@ufma.br \\ * Correspondence: egmoura@elointernet.com.br; Tel.: +55-98-99976-7123
}

Received: 17 February 2018; Accepted: 20 March 2018; Published: 29 March 2018

\begin{abstract}
Gypsum combined with leguminous residue may extend rootability and improve growth and maize grain yield. The aim of this study was to evaluate the combined effects of gypsum and leguminous residue on soil rootability in the root zone and on maize grain yield in a cohesive tropical soil. We used seven treatments: (i) control; (ii) urea; (iii) leguminous; (iv) $6 \mathrm{t} / \mathrm{ha}$ of gypsum with leguminous or (v) with urea or (vi) with both; and (vii) $12 \mathrm{t} /$ ha of gypsum with urea and leguminous. Gypsum was applied in January 2010 and soil samples were analyzed in 2012-2015. Maize was sown in 2011-2013 and 2015, when maize yield was determined. Soil penetration strength and the analysis of plant tissue was performed in 2015. The leaf area index, nitrogen accumulation amount, total $\mathrm{N}$ concentration and amount of $\mathrm{N}$ remobilization were also determined in 2015. Gypsum with leguminous residue modified the root zone by increasing calcium and organic matter levels and by reducing soil penetration strength. The leaf area index and the remobilization of nitrogen to grains increased, due to greater uptake before and after tasseling. The gypsum and leguminous residue combination is a more suitable strategy to improve agrosystems in cohesive soils of the humid tropics.
\end{abstract}

Keywords: calcium; penetration strength; nitrogen remobilization

\section{Introduction}

Cohesive soils derived from clastic sedimentary rock, with low contents of aggregator elements, like calcium and elemental iron, are widespread in the tropics [1]. In that soil, also known as hardsetting soil [2], crops can exploit only a thin surface layer to sustain development due to an increase of fine particles and decreased organic carbon at lower depths, which renders the deeper layers hard and inhospitable to root growth. In these circumstances, rooting is affected by depth, and any subsoil constraints can limit crop growth when the stock of water and nutrients is not sufficient in this soil volume [3].

In tropical conditions, due to the high atmospheric evaporative demand, the actual transpiration rate may be less than the potential transpiration rate even with high soil water potential, which can lead to a loss of turgidity, decreased carbon uptake, crop growth and yield [4]. Benjamin et al. [5] suggested a soil physical indicator expressed as "water stress day" to designate the total number of days when soil moisture contents is sufficiently low to cause water stress which harms crop growth. 
In cohesive sandy loam soil in tropical regions, water stress days can be counted from four days without rain, according to Moura et al., 2012 [6].

The uptake of nutrients by crops is closely related to rootability conditions in the soil: greater root length densities result in greater amounts of nutrients uptaken and fewer nutrients losses by leaching beyond the root zone, mainly in weathered tropical soils due to the high rainfall and low nutrient retention capacity [7]. Therefore, enhancing the volume of soil explored by crops is crucial to increasing water and nutrient use efficiency and enhancing economic feasibility of the crop systems in the tropics.

Strategies to reduce cohesion and enhance soil rootability have been recommended through appropriate application of certain techniques including: (i) mechanical loosening such as deep ripping; (ii) by incorporating biomass in the soil to increasing organic matter; (iii) use of mulching; and (iv) gypsum application [8-11]. Ripping cohesive soil without removing the causes of compaction might not improve yield. Each time the soil is tilled, it is aerated, which reduces the organic matter level and accelerates the process of re-compaction, increasing strength in cohesive soil after a year or less [12]. Unfortunately, in tropical regions, accumulation of organic matter, which could mitigate negative effects of cohesion on soil rootability, is impaired by conditions that favor fast decay of incorporated biomass [13].

Mulching with surface residues has been recommended as it provides soil cover and decreases the water evaporation rate, delays soil moisture loss, and improves soil rootability [14]. Furthermore, the presence of polysaccharides and fungal activity linked to the production of proteins of the glomalin-type derived from residue addition has been found to reduce soil disintegration, mainly through the slaking mechanisms [11]. However, it was observed that increased temperature and precipitation frequently correlate with accelerated rates of biomass decay, which can lead to loss of useful products from decomposition [15]. In addition, improvements in soil structural properties with crop residue mulch may only be effective near the soil surface [16].

To extend rootability to lower soil depths, some authors recommend using calcium as a "flocculating" agent to improve soil structure by reducing the dispersion of the clay $[17,18]$. However, this practice remains questionable as the effects of calcium on aggregation seems to be positive only in sandy-kaolinitic or clayey-kaolinitic dominant soils [19]. On the other hand, some authors have emphasized positive interactions between calcium and organic compost matter derived from residue, which could enhance soil structure in the root zone $[19,20]$.

Therefore, we hypothesized that using gypsum combined with leguminous residue applied on the soil surface may improve physical conditions of soil as a strategy to increase productivity and sustainability of agrosystems of the humid tropics. The aim of this work was to evaluate the combined effects of gypsum with leguminous residue on calcium and organic-C contents in the root zone and as this may affect soil penetration strength, nitrogen uptake and maize yield components in a sandy loam soil prone to cohesion.

\section{Materials and Methods}

\subsection{Experimental Design}

This study was conducted in five growing seasons (2011-2015) at Maranhão State University, Brazil $\left(2^{\circ} 30^{\prime} \mathrm{S}, 44^{\circ} 18^{\prime} \mathrm{W}\right)$. The region has a hot and semi-humid equatorial climate with two well-defined seasons: (i) a rainy season that extends from January to June; and (ii) a dry season with a marked water deficit from July to December. The annual average temperature is approximately $27^{\circ} \mathrm{C}$, the maximum temperature is $37^{\circ} \mathrm{C}$, and the minimum temperature is $23{ }^{\circ} \mathrm{C}$. The mean rainfall $(\mathrm{mm})$ during the experimental period (2011 to 2015) was $1439 \mathrm{~mm}$ year $^{-1}$, below the general average of the region [21].

The local soils displayed cohesive characteristics (determined by relationship between penetration strength and volumetric water content of soil) [6,22] and they were classified as Arenic Hapludults [23]. Before the first sowing of the experimental area in December of 2010, the chemical and physical properties of soil were determined as follows: $\mathrm{pH} 4.0$ (in $\mathrm{CaCl}_{2}$ ); $20 \mathrm{~kg}$ of organic carbon (C); $15 \mathrm{mg} / \mathrm{dm}$ of phosphorus $(\mathrm{P}) ; 25 \mathrm{mmol}_{\mathrm{c}} / \mathrm{dm}$ of potential acidity $(\mathrm{Al}+\mathrm{H}) ; 15 \mathrm{mmol}_{\mathrm{C}} / \mathrm{dm}$ of calcium $(\mathrm{Ca}) ; 9 \mathrm{mmol}_{\mathrm{c}} / \mathrm{dm}$ 
of magnesium $(\mathrm{Mg}) ; 1 \mathrm{mmol}_{\mathrm{c}} / \mathrm{dm}$ of potassium $(\mathrm{K}) ; 50 \mathrm{mmol}_{\mathrm{c}} / \mathrm{dm}$ of cation exchange capacity (CEC); $50.0 \%$ of percentage base saturation; $300 \mathrm{~g} / \mathrm{kg}$ of coarse sand, $545 \mathrm{~g} / \mathrm{kg}$ of fine sand, $61 \mathrm{~g} / \mathrm{kg}$ of silt; $90 \mathrm{~g} / \mathrm{kg}$ of clay. In January 2011 the area was limed with $1 \mathrm{t} / \mathrm{ha}$ of surface-applied lime, corresponding to 390 and $130 \mathrm{~kg} / \mathrm{ha}$ of $\mathrm{Ca}$ and $\mathrm{Mg}$, respectively. In this same period, natural gypsum was applied at a rate of 6 or $12 \mathrm{t} /$ ha in plots predetermined to receive these treatments, which corresponds to 1.02 and $2.04 \mathrm{~kg} / \mathrm{ha}$ of $\mathrm{Ca}$, respectively. The gypsum grain size was such that $95 \%$ by weight passed through a $0.25-\mathrm{mm}$ screen mesh.

The area had been fallow since 1990 and supported a native species of grass, which was removed using a glyphosate application. The experiment was conducted under no-tillage mulch system, with planting maize seed by hand, and the experimental plot size was $4 \times 8 \mathrm{~m}$. Some remaining weed was removed manually. The study followed a randomized block design with four replications of the following treatments: control (C), urea (U), leguminous (L), $6 \mathrm{t} /$ ha of gypsum with leguminous (LG6) or with urea (UG6), or with both (LUG6) and $12 \mathrm{t} /$ ha of gypsum with urea and leguminous (LUG12). Gypsum was applied in January 2010 and soil samples were analyzed in 2012-2015. Maize was sown in 2011-2013 and 2015, when maize yield was determined. Soil penetration strength and the analysis of plant tissue was performed in the year of 2015. The leaf area index, nitrogen accumulation amount, total $\mathrm{N}$ concentration and amount of $\mathrm{N}$ remobilization, also were determined in 2015. The treatment Urea was created in 2015 to provide comparative data in N contents and yields components of maize.

Maize (cultivar AG 7088) was sown at the beginning of the rainy season in 2011-2013 and 2015, with spacing $80 \mathrm{~cm}$ between rows and $25 \mathrm{~cm}$ between plants. In January of 2014, soybean was sown as crop rotation. The fertilization (commonly recommended for the region) for maize and soybean consisted of applying $80 \mathrm{~kg} / \mathrm{ha}$ of phosphate $\left(\mathrm{P}_{2} \mathrm{O}_{5}\right)$ from triple superphosphate, $120 \mathrm{~kg} / \mathrm{ha}$ of $\mathrm{K}_{2} \mathrm{O}$ from potassium chloride and $5 \mathrm{~kg} / \mathrm{ha}$ of zinc $(\mathrm{Zn})$ in the form of zinc sulfate. Residues from Gliricidia sepium (gliricidia) and Acacia mangium (acacia) were applied at $6 \mathrm{t} /$ ha for each legume (a total of $12 \mathrm{t} /$ ha per year), a rate that is commonly applied in alley cropping systems according to Aguiar et al. [24]. The legume residues were applied in the years 2011-2015, in the form of fresh branches. The quantities of nutrients added per year, calculated based on quality parameters of leguminous residues was: $342 \mathrm{~kg} / \mathrm{ha}$ of N, $27.2 \mathrm{~kg} / \mathrm{ha}$ of $\mathrm{P}, 60.6 \mathrm{~kg} / \mathrm{ha}$ of $\mathrm{K}, 177.6 \mathrm{~kg} / \mathrm{ha}$ of $\mathrm{Ca}, 33.0 \mathrm{~kg} / \mathrm{ha}$ of $\mathrm{Mg}$. The total amount of urea and leguminous residues were divided and applied at the time of sowing and 45 days after planting.

\subsection{Soil Sampling and Analyses}

Soil samples were collected in June 2012-2015 at depths of 0-10, 10-20 and 20-30 cm. Three replicates were collected using a Dutch auger 3-inch diameter. The samples from each point were passed through a 2-mm screen mesh and then air-dried prior to the analyses. Each sample was analyzed using ion exchange resin as an extractor for $\mathrm{Ca}$, which was measured using a Varian inductively coupled plasma instrument (Walnut Creek, CA, USA), model ES-720, with Software ICP Expert II., based on Raij et al. [25]. The table of critical level defined by Heckman [26] was used to construct the graph of the estimated soil calcium content. Portions of the samples collected at a depth of $0-0.10$ and $0.10-0.20 \mathrm{~m}$ were separated to determine organic carbon following wet oxidation followed by titration with ferrous ammonium sulfate method described by Tiessen and Moir [27]. The table of critical level defined by Hazelton and Murphy [28] was used to construct the graph of the estimated soil carbon content.

The soil penetration strength and soil moisture were measured at depths of $0-0.05,0.05-0.10$, $0.10-0.15,0.15-0.20$, and $0.20-0.25 \mathrm{~m}$ with three replicates per plot, in April of 2015, after 4 days without rain. The soil penetration strength was measured using a digital penetrometer (Falker, Porto Alegre, Brazil) with $1 \mathrm{~cm}$ gradations. The table of critical level defined by Hazelton and Murphy [28] was used to construct the graph of the soil penetration strength. Soil moisture was determined by gravimetric method, using samples obtained in the same period of assessment of soil penetration strength, at three points 
along the given line. In the year 2015, urea treatment was not sampled for soil chemical and physical analyses, only the control was sampled to represent the treatment without gypsum with bare soil.

\subsection{Plant Analysis, Yield Components and Water Stress Days}

The analysis of plant tissue was only performed in 2015. The leaf area index (LAI) was calculated using the area of each leaf from the formula $0.75 \times$ length $\times$ width. The values of length and width were obtained from the biometric measurements of the largest leaf of ten plants per plot chosen randomly [29]. Nitrogen accumulation amount was measured on two occasions, at tasseling (NT; or approximately 1 week before anthesis) and at the physiological maturity stage (total nitrogen accumulated and amount of nitrogen in grain). At each sampling, five plants from each plot were randomly selected and separated into leaves, stalks and, at the second sampling, reproductive components. All these plant materials were dried at $60^{\circ} \mathrm{C}$ for $3-4$ days to obtain a constant weight. Subsamples were collected and ground to pass through a 1-mm screen mesh. Total $\mathrm{N}$ concentration was determined in the maize following sulfuric acid-hydrogen peroxide $\left(\mathrm{H}_{2} \mathrm{SO}_{4}-\mathrm{H}_{2} \mathrm{O}_{2}\right)$ digestion according to the standard method described by Cottenie [30]. Based on the measurements of plant dry matter (DM) and $\mathrm{N}$ uptake, we calculated the amount of $\mathrm{N}$ remobilization (NR): [(DM in all vegetative organs at tasseling $\times \mathrm{N}$ concentration at tasseling $)-(\mathrm{DM}$ in all vegetative organs at maturity $\times \mathrm{N}$ concentration in all vegetative organs at maturity)]. The amount of $\mathrm{N}$ uptaken post -tasseling (NPT) was calculated: ( $\mathrm{N}$ accumulation amount in all organs at maturity-N accumulation amount in all organs at tasseling).

The yield components were only analyzed in the year of 2015. The weight of the ears, number of grains per ear, and weight of grains were determined, and all the values were adjusted according to moisture level of $145 \mathrm{~g} \mathrm{~kg}^{-1}$. We determined the weight of 100 grains by weighing the grain on a scale with an accuracy of $0.0001 \mathrm{~g}$. The maize yield was determined at the final harvest or at physiological maturity in 2011-2013 and 2015, which was assessed in a $12 / \mathrm{m}^{2}$ area.

The cumulative water stress days were calculated considering the number of days after four days without rain following findings by Moura et al., 2009 and Benjamin et al., 2003 [5,22], using climate data collected in a Remote Automated Weather Station located next to the experimental area.

Results were subjected to analysis of variance (ANOVA) and means were compared by Duncan's test $(p<0.05)$ whenever the F-test was significant, using InfoStat software (InfoStat Group, College of Agricultural Sciences, National University of Córdoba, Córdoba, Argentina).

\section{Results}

\subsection{Enhancement of Root Environment and Responses in Maize Grain Yield}

In the $0-10 \mathrm{~cm}$ layer the calcium content was increased by applying gypsum just in the years 2012 and 2013 (Figure 1a). Five years after (2015) of application gypsum and lime, all treatments showed very high critical levels of calcium content in the $0-0.10 \mathrm{~m}$ layer. In the $0.10-0.20 \mathrm{~m}$ layer (Figure $1 \mathrm{~b}$ ) this content was high in all treatments. While in the $0.20-0.30 \mathrm{~m}$ depth layer (Figure 1c), was low in the control, medium in L, LUG6 and UG6 and high in the treatments LG6 and LUG12. In the same year (2015) only in the treatment with gypsum without leguminous residue (UG6), the calcium content was not significantly higher than from those with lime alone (C and $\mathrm{L})$, in the $0-0.30 \mathrm{~m}$ depth layer.

In the plots with leguminous residue the organic- $C$ content was higher than in the uncovered plots. In the $0-0.10 \mathrm{~m}$ layer, the organic-C content was higher in treatment UG6 than in the control treatment, with larger differences in the years 2012-2015 (Figure 2a). In the 10-20 cm layer organic- $C$ was higher when was used gypsum with leguminous than in plots with leguminous alone. All treatments showed moderate critical levels of organic- $C$ content from the first until the last year in the $0-10 \mathrm{~cm}$ layer, while it was low in the 10-20 cm layer (Figure 2b). There was no increase in organic-C content from the first to fourth years, even in the treatments with leguminous residue. 
(a)

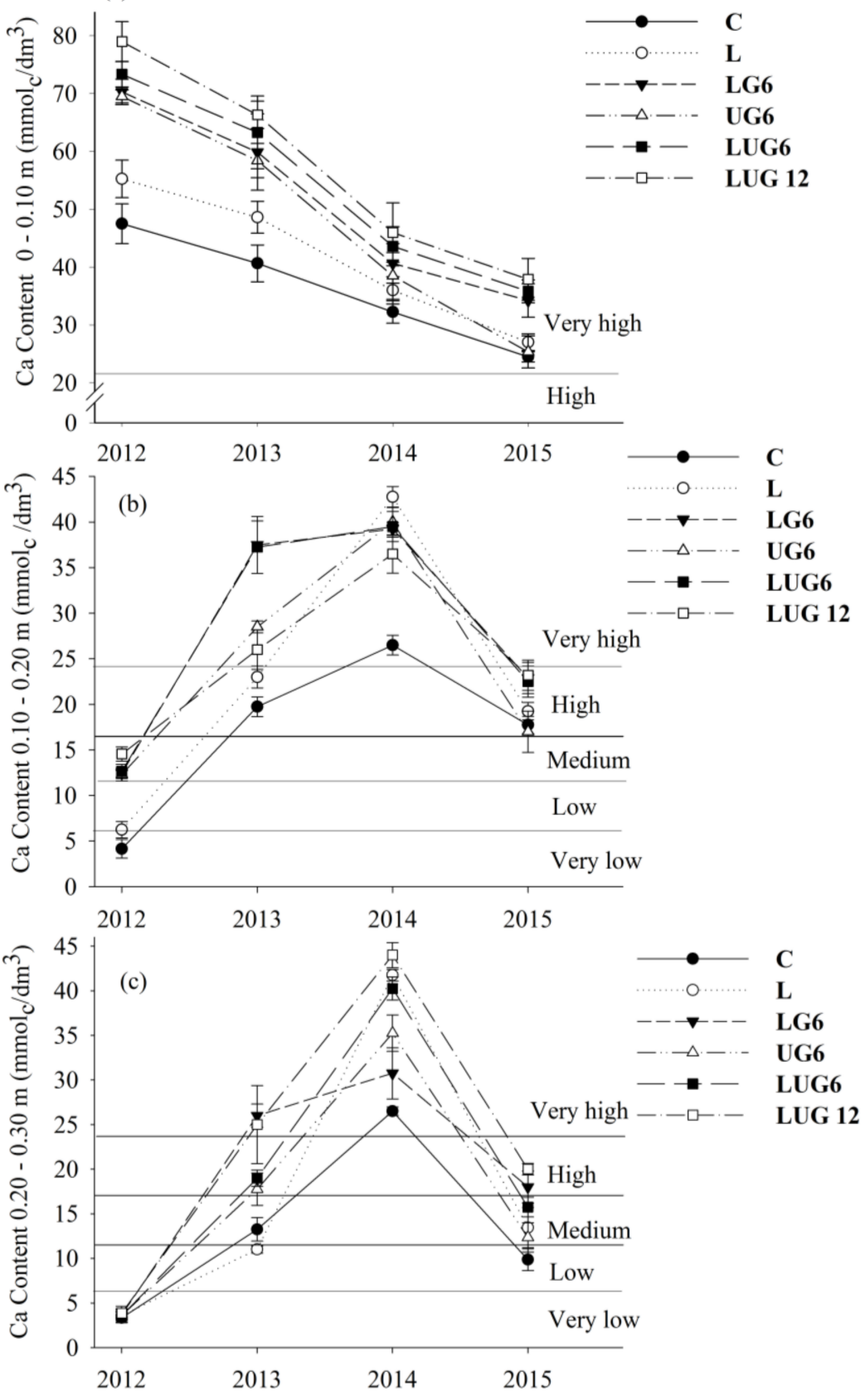

Figure 1. Calcium content in the soil, in the depth of $0-0.10$ (a), $0.10-0.20$ (b) and $0.20-0.30 \mathrm{~m}$ (c) in 2012-2015. C = control; $\mathrm{L}=$ leguminous; LG6 = leguminous and $6 \mathrm{t} / \mathrm{ha}$ of gypsum; UG6 = urea and $6 \mathrm{t} /$ ha of gypsum; LG6 = leguminous, urea and $6 \mathrm{t} /$ ha of gypsum; LUG12 = leguminous, urea and $12 \mathrm{t} / \mathrm{ha}$ of gypsum. Bars show standard errors. Horizontal bars mean the critical levels by Hechman (2006) [26].

The soil moisture was higher in the treatments with biomass, but it was not different between them. The soil strength was lower in the plots with gypsum plus leguminous residue in the 0.05-0.20 m layer compared to the control plots (Figure 3). There was no significant difference between the treatments in the 0-0.05 m layer where all treatments were loose. Except to LUG12 and LUG6, from the 10-15 cm layer all the treatments were dense four days after the rain. In the 20-25 cm layer, the treatments without cover (UG6 and C) were very dense. In the plots with gypsum, urea and leguminous, the effect of the gypsum on decreasing of soil strength was up to $25 \mathrm{~cm}$, compared to the control. 

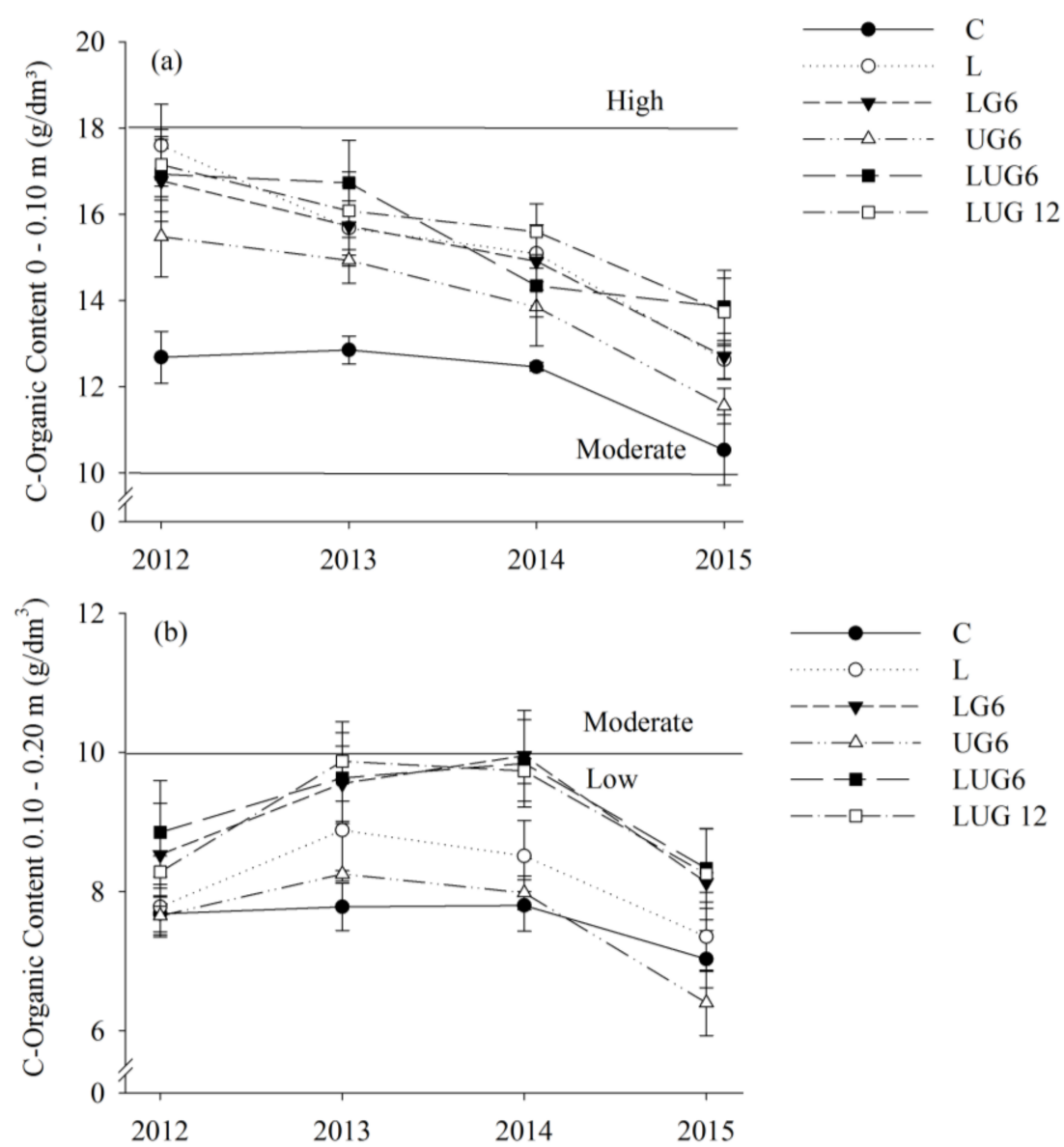

Figure 2. Organic-carbon content in the soil, in the depth of 0-0.1 (a) and 0.10-0.20 (b) $\mathrm{m}$ in 2012-2015. $\mathrm{C}=$ control; $\mathrm{L}=$ leguminous; $\mathrm{LG} 6=$ leguminous and $6 \mathrm{t} /$ ha of gypsum; $\mathrm{UG} 6=$ urea and $6 \mathrm{t} / \mathrm{ha}$ of gypsum; LUG6 = leguminous, urea and $6 \mathrm{t} /$ ha of gypsum; LUG12 = leguminous, urea and $12 \mathrm{t} /$ ha of gypsum. Bars show standard errors. Horizontal bars mean the critical levels by Hazelton \& Murphy (2007) [28].
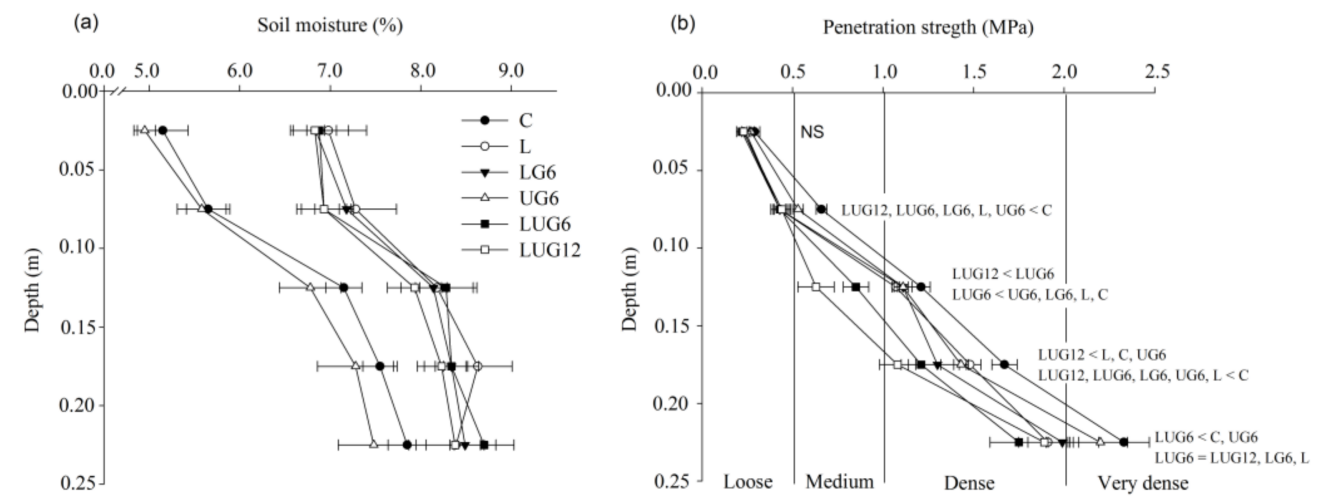

Figure 3. (a) Gravimetric soil moisture and (b) penetration strength after 4 days without rain in 2015. $\mathrm{C}=$ control; $\mathrm{L}=$ leguminous; LG6 = leguminous and $6 \mathrm{t} / \mathrm{ha}$ of gypsum; UG6 = urea and $6 \mathrm{t} / \mathrm{ha}$ of gypsum; LUG6 = leguminous, urea and $6 \mathrm{t}$ /ha of gypsum; LUG12 = leguminous, urea and $12 \mathrm{t} / \mathrm{ha}$ of gypsum. NS, not significant. Vertical bars mean the critical levels by Hazelton \& Murphy (2007) [28]. 
The maize yield was impaired in 2012 in all treatments (Figure 4). In this year, the maize underwent nine water stress days, five of which were just in the grain filling stage (Figure 5). In the other years, the water stress days were three in 2011, two in 2013 and four in 2015.

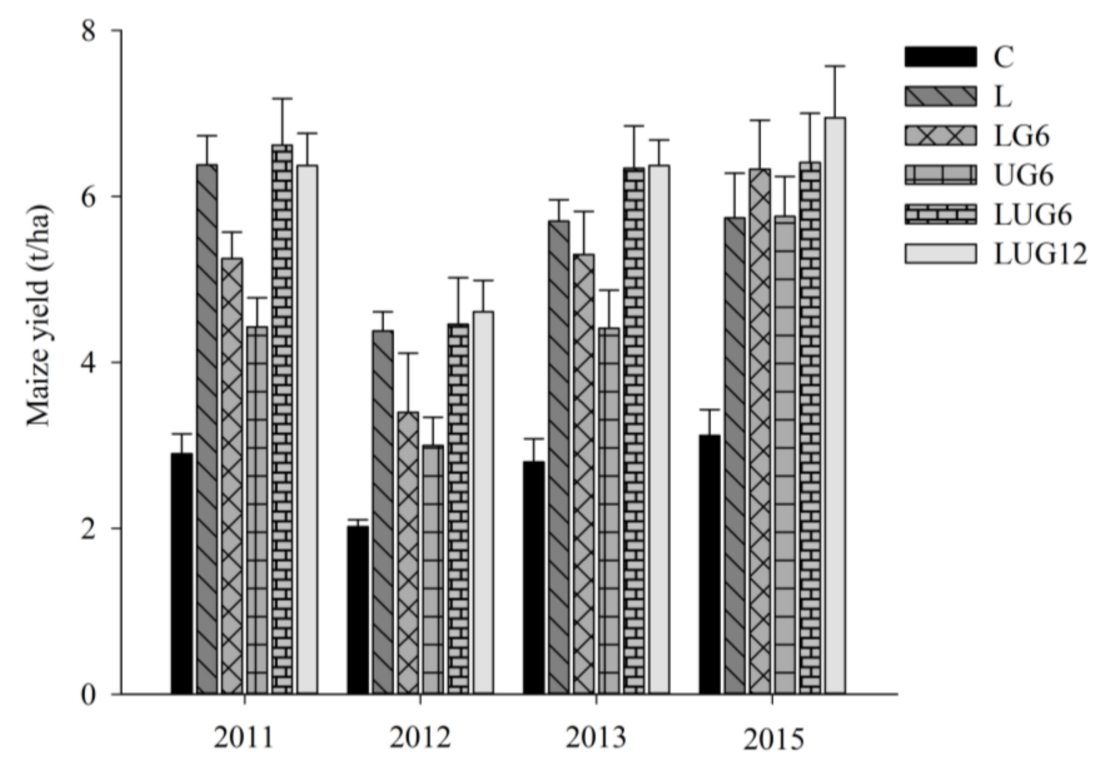

Figure 4. Maize yield in the experimental area in 2011-2013 and 2015.C = control; L = leguminous; LG6 = leguminous and $6 \mathrm{t} /$ ha of gypsum; UG6 = urea and $6 \mathrm{t} / \mathrm{ha}$ of gypsum; LUG6 = leguminous, urea and $6 \mathrm{t} /$ ha of gypsum; LUG12 = leguminous, urea and $12 \mathrm{t} /$ ha of gypsum. Bars show standard errors.

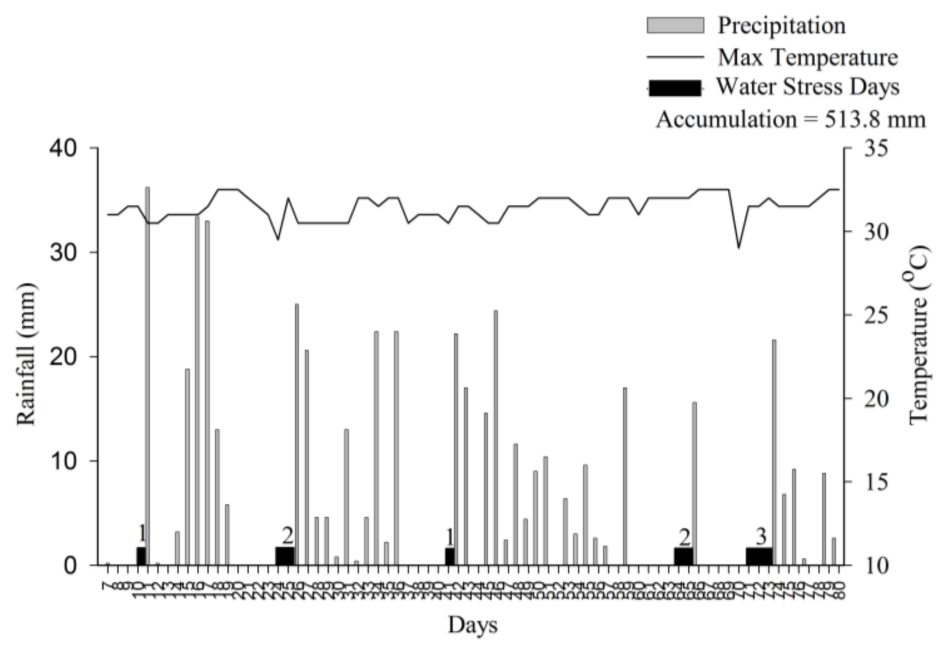

Figure 5. Rainfall, maximum temperature (Max temperature) and water stress days in the experimental area during 6-80 days after sown of maize in 2012.

\subsection{The Leaf Area Index, Nutrient Uptake and Nitrogen Remobilization}

The leaf area index was larger in the treatments with leguminous residue and gypsum, without differences between them (Table 1). There was no significant difference between the treatments with urea and the control. Differences in amount of nitrogen at tasseling and amount of nitrogen remobilization were substantial and both leguminous residue and gypsum increased the nitrogen accumulated in the vegetative stage and remobilized, so that L > C and UG6 $>$ U. The amount of nitrogen at tasseling and the amount of nitrogen remobilization were higher in the treatments with urea, leguminous residue, and gypsum (LUG6, LUG12) and were lower in the plots without leguminous 
residue or gypsum $(\mathrm{U}, \mathrm{C})$. In the other treatments nitrogen uptake was intermediate and without significant difference between them.

Table 1. Leaf area index (LAI), amount of nitrogen at tasseling (NT), amount of nitrogen remobilized (NR), amount of nitrogen uptake post-tasseling (NPT), amount of nitrogen in grain (NG), total nitrogen accumulated (TN), dry matter at maturity (DM), in the experimental area in 2015.

\begin{tabular}{cccccccc}
\hline & C & U & L & LG6 & UG6 & LUG6 & LUG12 \\
\hline LAI $\left(\mathrm{m}^{2} \mathrm{~m}^{-2}\right)$ & $2.45 \mathrm{~b}$ & $2.58 \mathrm{~b}$ & $3.06 \mathrm{a}$ & $3.03 \mathrm{a}$ & $3.04 \mathrm{a}$ & $3.08 \mathrm{a}$ & $3.29 \mathrm{a}$ \\
NT $\left(\mathrm{Kg} \mathrm{ha}^{-1}\right)$ & $34.69 \mathrm{c}$ & $57.98 \mathrm{c}$ & $76.38 \mathrm{~b}$ & $69.43 \mathrm{~b}$ & $75.45 \mathrm{~b}$ & $103.16 \mathrm{a}$ & $94.28 \mathrm{a}$ \\
NR $\left(\mathrm{Kg} \mathrm{ha}^{-1}\right)$ & $8.38 \mathrm{c}$ & $13.68 \mathrm{c}$ & $38.67 \mathrm{~b}$ & $37.65 \mathrm{~b}$ & $27.89 \mathrm{~b}$ & $56.41 \mathrm{a}$ & $52.35 \mathrm{a}$ \\
NPT $\left(\mathrm{Kg} \mathrm{ha}^{-1}\right)$ & $27.24 \mathrm{c}$ & $28.00 \mathrm{c}$ & $41.19 \mathrm{ab}$ & $50.46 \mathrm{a}$ & $37.19 \mathrm{~b}$ & $42.20 \mathrm{a}$ & $45.16 \mathrm{a}$ \\
NG $\left(\mathrm{Kg} \mathrm{ha}^{-1}\right)$ & $39.43 \mathrm{~d}$ & $52.18 \mathrm{~d}$ & $72.28 \mathrm{bc}$ & $88.35 \mathrm{ab}$ & $70.14 \mathrm{c}$ & $88.61 \mathrm{ab}$ & $94.50 \mathrm{a}$ \\
TN $\left(\mathrm{Kg} \mathrm{ha}^{-1}\right)$ & $61.93 \mathrm{c}$ & $85.98 \mathrm{bc}$ & $117.57 \mathrm{ab}$ & $119.89 \mathrm{a}$ & $112.64 \mathrm{ab}$ & $145.36 \mathrm{a}$ & $139.44 \mathrm{a}$ \\
$\mathrm{DM}\left(\mathrm{Mg} \mathrm{ha}^{-1}\right)$ & $6.72 \mathrm{e}$ & $9.14 \mathrm{~d}$ & $11.21 \mathrm{c}$ & $12.95 \mathrm{ab}$ & $11.37 \mathrm{bc}$ & $13.46 \mathrm{a}$ & $13.23 \mathrm{ab}$ \\
\hline
\end{tabular}

$\mathrm{C}=$ control; $\mathrm{U}=$ urea; $\mathrm{L}=$ leguminous; LG6 = leguminous and $6 \mathrm{t} \mathrm{ha}^{-1}$ of gypsum; UG6 = urea and $6 \mathrm{t} \mathrm{ha}^{-1}$ of gypsum; LUG6 = leguminous, urea and $6 \mathrm{tha}^{-1}$ of gypsum; LUG12 = leguminous, urea and $12 \mathrm{tha}^{-1}$ of gypsum. Note: Different letters in the same row indicate differences at the $5 \%$ level by Duncan's test.

The greatest amount of nitrogen uptake post-tasseling was shown to be in the treatments with leguminous residue (Table 1). Thus, the treatment LG6 was 26\% higher than UG6 and L was 32\% higher than U. There were no significant differences between the treatments LUG12 and LG6. The amount of nitrogen in grain was also greater in the treatments with gypsum combined with leguminous residue. There was no difference among the treatments LUG12, LUG6, and LG6, which were higher than in other treatments, except for L. Once again, the treatments $U$ and control showed the lowest values of amount of nitrogen in grain. The total N accumulated was greater in LUG6, LUG12, and LG6 than in U and the control where it was not different. The dry matter at maturity was higher in the treatments with leguminous residue, urea and gypsum and it was lower in the plots without gypsum and leguminous residue. Both leguminous, urea and gypsum increased the dry matter so that $\mathrm{L}$ and $\mathrm{U}>\mathrm{C}$ and $\mathrm{UG} 6>\mathrm{U}$.

Greater differences were shown by the weight of ear and number of grains per ear, which was higher in LUG12 and LUG6 than in treatment with urea alone and the control treatment, which showed the lowest values (Table 2). Differences in the weight of 100 grain among treatments were small and all the treatments were higher than the control, except for the treatment with urea alone. The weight of grains was greater in the treatments LUG12, LUG6 and LG6, than in the control and urea treatments alone, which did not show significant differences between them, but the UG6 and L treatments were greater than the control.

Table 2. Weight of ear, number of grains ear ${ }^{-1}$, weight of 100 grains and weight of grains in the experimental area in 2015.

\begin{tabular}{|c|c|c|c|c|c|c|c|}
\hline & $\mathrm{C}$ & $\mathbf{U}$ & $\mathbf{L}$ & LG6 & UG6 & LUG6 & LUG12 \\
\hline Weight of ear (g) & $118.48 \mathrm{c}$ & $162.10 \mathrm{~b}$ & $188.71 \mathrm{ab}$ & $183.85 \mathrm{ab}$ & $190.61 \mathrm{ab}$ & $198.26 \mathrm{a}$ & $199.40 \mathrm{a}$ \\
\hline Number of grains ear ${ }^{-1}$ & 447 c & $555 \mathrm{~b}$ & $619 \mathrm{ab}$ & $619 \mathrm{ab}$ & $618 \mathrm{ab}$ & $624 \mathrm{a}$ & $628 \mathrm{a}$ \\
\hline Weight of 100 grains $(\mathrm{g})$ & $26.24 \mathrm{~b}$ & $28.99 \mathrm{ab}$ & $30.50 \mathrm{a}$ & 29.65 a & 30.84 a & $31.96 \mathrm{a}$ & $31.52 \mathrm{a}$ \\
\hline Weight of grains $\left(t \mathrm{tha}^{-1}\right)$ & $3.12 \mathrm{c}$ & $4.33 \mathrm{bc}$ & $5.74 \mathrm{ab}$ & $6.33 \mathrm{a}$ & $5.76 \mathrm{ab}$ & $6.41 \mathrm{a}$ & $6.95 \mathrm{a}$ \\
\hline
\end{tabular}

\section{Discussion}

The combination of the high rainfall levels of the study period $(7194 \mathrm{~mm})$ with the high water infiltration rate of the soil can explain the fast downward movement of calcium in the soil profile (Figure 1). In the same soil, Moura et al. [22] found a water infiltration rate of around $70 \mathrm{~mm} \mathrm{~h}^{-1}$. 
Furthermore, in most sandy loam soils with a small buffering capacity in which cations do not interact strongly with the soil matrix, the applied Ca fertilizers result in a higher concentration in the soil solution than may be leached if large amounts of water percolate down into the soil profile [31]. This can also explain the small differences in calcium content between the treatments with 6 or $12 \mathrm{t}$ per ha of gypsum. In contrast, the formation of cation bridges with products derived from decomposition of the applied biomass can account for the highest calcium level in the plots with leguminous residue. Polyvalent cation "bridges" can be formed between negatively charged particles, essentially binding organic molecules together or to minerals [20]. The major cation involved in the formation of bridges is $\mathrm{Ca}^{2+}$; therefore, interactions between calcium organic macromolecules result in the formation of strong bonds involving $\mathrm{Ca}^{2+}$ organic colloids. Furthermore, variation in exchangeable cation concentrations can affect fluxes of dissolved organic matter by stabilizing negatively charged organic matter through sorption to positively charged cations [32]. The bond between polyvalent cations and negatively charged organic matter functional groups is not easily reversible and surfaces of organic materials will be least accessible for microbial activity. This flocculation prevented biological, chemical, or physical breakdown, which explains the differences in organic- $C$ in the plots with gypsum, compared to treatment with leguminous residue alone (Figure 2) [33]. Although higher amount of calcium added in L (calcium derived from leguminous + lime) and UG6 (calcium derived from gypsum + lime) no difference was found between the control and these treatments, where the calcium contents was lower than in LG6. That finding confirm the effects of the positive interactions between leguminous and gypsum to increased calcium contents in $0.10-0.30 \mathrm{~m}$ layer.

The soil strength above the $0.10-0.15 \mathrm{~m}$ layer just 4 days after the rain ( $>1.5 \mathrm{MPa})$, in the control treatment, shows the need for enhancing the depth of the rootable layer (Figure 3). Provided that, the differences among treatments with biomass cannot be explained only by small and not significant variations in soil moisture, the biomass and gypsum combined were able to improve the soil root environment. According to Shepherd et al. [34], residue application may contribute to an environment favorable to rootability promoting the formation of 'ephemeral structures' by increasing the free light fraction of soil organic matter. In turn, the improvements caused by gypsum are both direct (increasing flocculation and aggregation in the subsoil) and indirect (improving root activity, which leads to greater soil aggregation) [9].

Anikwe et al. [17] also reported the positive effect of gypsum on soil physical and chemical properties from a degraded tropical soil because of $\mathrm{Ca}^{2+}$ applied via gypsum to flocculate soil particles thereby creating supportive soil conditions. Furthermore, Wuddivira and Camps-Roach [19] also reported that calcium in addition to organic matter could improve aggregation in a sandy-kaolinitic soil by increasing aggregate stability resulting from the formation of strong bonds involving $\mathrm{Ca}^{2+}$ bridges, which increases soil rootability. It is worth highlighting that one year after the application, the leguminous residue and gypsum was not able to mitigate the impact of water stress in the treatments with highest yield (Figure 4). Thus, in the 2012 the yield reflected the amount of water stress the plant was subjected to during the growing season (cumulative water stress days), mainly during the grain filled stage. Unfortunately, mulch and soil amendment were not able to avoid water stress effect on maize grain yield (Figure 5).

The differences in the leaf area index showed that the mulch, more than applied gypsum or nitrogen, increased leaf expansion, which is one of the most sensitive processes to crop stress and can reduce the intercepted photosynthetically active radiation (Table 1). Dry matter production increases linearly with the amount of solar radiation intercepted by the current leaf area [35]. According to Sadras and Milroy [36], reduced leaf area is probably the most obvious mechanisms by which crops restrict water loss in response to soil-stress. Indeed, four days of water stress during the vegetative stage could have harmed leaf growth in the uncovered plots in the year 2015. In turn, as the plants with mulch also showed higher accumulated $\mathrm{N}$ at tasseling stage, the increased leaf area index in the covered plots may be also due to greater nitrogen contents in leaves. During vegetative growth, $\mathrm{N}$ supply has a marked influence on leaf area development. The main effect is on leaf expansion due to 
increase in availability of cytokinins, which play a key role in leaf elongation rate through cell division, or cell elongation at the leaf base in young leaves [37].

Both, leguminous and gypsum increased the $\mathrm{N}$ uptake at a vegetative stage. Additionally, when combined (in LUG6), they increased $\mathrm{N}$ uptake around $40 \%$ by tasseling stage, compared to treatment with urea alone (U) (Table 1). The absorption of $\mathrm{N}$ is highly dependent on root development and therefore soil rootability, while root system growth results in greater uptake and less $\mathrm{N}$ leaching [38]. In the same way, the $\mathrm{N}$ remobilization was also affected by the gypsum and leguminous residue with great differences (around 85\%) between LUG6 and C. As during the grain-filling period, $\mathrm{N}$ uptake is generally insufficient for high demand of the seeds; remobilization in the different plant organs is needed to route nitrogen to the grains. The relative flow and remobilization of nitrogen to the grain during the grain-filling period can be analyzed in terms of source of nitrogen to redistribution and sites for reutilization and storage [39]. Therefore, the variation in the amounts of $\mathrm{N}$ remobilized was similar to those amounts of $\mathrm{N}$ at the tasseling stage. On the other hand, $\mathrm{N}$ depletion, tends to accelerate the senescence of leaves, reducing photosynthesis and decreasing ear weight [40]. This reveals the importance of amount of nitrogen uptake post-tasseling, increased by the gypsum and leguminous combination. Differences in the amount of $\mathrm{N}$ uptake post-tasseling between the treatment LUG6 $\left(42.2 \mathrm{Kg} \mathrm{ha}^{-1}\right)$ and $\mathrm{U}\left(28.0 \mathrm{Kg} \mathrm{ha}^{-1}\right)$ is crucial to demonstrate the positive effect of the gypsum-leguminous combination on $\mathrm{N}$ availability and uptake. Under high leaching conditions, only a sporadic supply of nitrogen in strips besides rows, as done when applying urea, may not meet $\mathrm{N}$ needs of maize after the tasseling stage [18]. Therefore, a slow-releasing nutrient supply from decomposition of legume residues and the enhancement of soil rootability made possible a higher $\mathrm{N}$ uptake, so that in LG6 (without urea) the total $\mathrm{N}$ accumulated was similar to LUG6 and LUG12 and was higher than in U. Both the urea and the leguminous residue increased the number of grains per ear and the weight of ears, but the weight of grain in LG6 was as high as in LUG6, which confirms the small effect of urea on the maize yield (Table 2). Indeed, while the weight of grains in the treatment $U$ was similar to the control, in the LG6 it was twice as higher compared to control. In addition to the greater nutrient available and uptake, the positive effects of leguminous residue and of gypsum on maize yield for this soil can be potentially attributed primarily to larger plant transpiration rates in covered soil and consequently higher $\mathrm{CO}_{2}$ assimilation rates, as reported by Moura et al. [22]. Both processes rely heavily on increased root length and on delayed soil drying, both of which are improved by mulching and gypsum.

\section{Conclusions}

Applying gypsum with leguminous residues modified the root zone by increasing the level of calcium and organic matter and reduced the soil strength compared with other treatments. In the maize crop, these changes increased the leaf area index and the nitrogen remobilization to grains due to greater uptake before and after tasseling. This positive effect on the physiological process also produced variations in maize grain yield, meaning that, rather than increase mineral fertilization alone, the gypsum with leguminous residue combination is a more suitable strategy to increase productivity and enhance sustainability of agrosystems of the humid tropics.

Acknowledgments: This work was undertaken as part of NUCLEUS, a virtual joint center to deliver enhanced N-use efficiency via an integrated soil-plant systems approach for the United Kingdom and Brazil. Funded in Brazil by FAPESP-São Paulo Research Foundation [grant number 2015/50305-8]; FAPEG—Goiás Research Foundation [grant number 2015-10267001479]; and FAPEMA-Maranhão Research Foundation [grant number RCUK-02771/16]; and in the United Kingdom by the Biotechnology and Biological Sciences Research Council [grant number BB/N013201/1] under the Newton Fund scheme.

Author Contributions: Emanoel Gomes de Moura conceived and designed the experiment; Stefanny Barros Portela, Vinicius Ribamar Alencar Macedo, Virley Gardeny Lima Sena and Carlos Cesar Martin Sousa performed the experiment and analyzed the data; Alana das Chagas Ferreira Aguiar contributed towards the writing and editing of the paper.

Conflicts of Interest: The authors declare no conflict of interest. 


\section{References}

1. Daniells, I.G. Hardsetting soils: A review. Soil Res. 2012, 50, 349-359. [CrossRef]

2. Giarola, N.F.B.; Silva, A.P.; Tormena, C.; Souza, L.S.; Ribeiro, L.P. Similaridades entre o caráter coeso dos solos e o comportamento hardsetting: Estudo de caso. Rev. Bras. Cienc. Solo 2011, 25, 239-247. [CrossRef]

3. Wong, M.T.F.; Asseng, S. Yield and environmental benefits of ameliorating subsoil constraints under variable rainfall in a Mediterranean environment. Plant Soil 2007, 297, 29-42. [CrossRef]

4. Denmead, O.T.; Shaw, R.H. The effects of soil moisture stress at different stages of growth on the development and yield of corn. Agron. J. 1960, 52, 272-274. [CrossRef]

5. Benjamin, J.G.; Nielsen, D.C.; Vigil, M.F. Quantifying effects of soil conditions on plant growth and crop production. Geoderma 2003, 116, 137-148. [CrossRef]

6. Moura, E.G.; Oliveira, A.K.; Coutinho, C.G.; Pinheiro, K.M.; Aguiar, A.C.F. Management of a cohesive tropical soil to enhance rootability and increase the efficiency of nitrogen and potassium use. Soil Use Manag. 2012, 28, 368-375. [CrossRef]

7. Dechert, G.; Veldkamp, E.; Brumme, R. Are partial nutrient balances suitable to evaluate nutrient sustainability of land use systems? Results from a case study in Central Sulawesi, Indonesia. Nutr. Cycl. Agroecosyst. 2005, 72, 201-212. [CrossRef]

8. Mulumba, L.N.; Lal, R. Mulching effects on selected soil physical properties. Soil Tillage Res. 2008, 98, $106-111$. [CrossRef]

9. Sumner, M.E. Gypsum improves subsoil root growth. In Proceedings of the International symposium "Root Reseacher and Aplications, BOKU, Viena, Austria, 2-4 September 2009.

10. Badorreck, A.; Krümmelbein, J.; Raab, T. Long-term effects of deep soil loosening on root distribution and soil physical parameters in compacted lignite mine soils. Geophys. Res. Abstr. 2015, 17, EGU2015-14990. Available online: http:/ / meetingorganizer.copernicus.org/EGU2015/EGU2015-14990.pdf (accessed on 24 March 2018).

11. Carrizo, M.E.; Alesso, C.A.; Cosentino, D.; Imhoff, S. Aggregation agents and structural stability in soils with different texture and organic carbon contents. Sci. Agric. 2015, 72, 75-82. [CrossRef]

12. Moussadek, R.; Mrabet, R.; Dahan, R.; Zouahri, A.; El Mourid, M.; Van Ranst, E. Tillage System Affects Soil Organic Carbon Storage and Quality in Central Morocco. Appl. Environ. Soil Sci. 2014, 2014, 654796. [CrossRef]

13. Christensen, B.T. Organic Matter in Soil-Structure, Function and Turnover; DIAS Report. Plant Production, 30; Danish Institute of Agricultural Sciences, Research Center Foulum: Tjele, Denmark, 2000.

14. Moura, E.G.; Marques, E.S.; Silva, T.M.B.; Piedade, A.; Aguiar, A.C.F. Interactions among leguminous trees, crops and weeds in a no-till alley cropping system. Int. J. Plant Prod. 2014, 8, 441-456. Available online: http:/ /ijpp.gau.ac.ir/article_1719_3de34834108cef844800c6fc10334a2d.pdf (accessed on 24 March 2018).

15. Wieder, R.W.; Cleveland, C.C.; Townsend, A.R. Controls over leaf litter decomposition in wet tropical forests. Ecology 2009, 90, 3333-3341. Available online: https:/ / scholarworks.umt.edu/cgi/viewcontent.cgi?referer= https: / / www.google.com.br / \&httpsredir=1\&article=1009\&context=decs_pubs (accessed on 24 March 2018). [CrossRef] [PubMed]

16. Blanco-Canqui, H.; Lal, R. Soil and crop response to harvesting corn residues for biofuel production. Geoderma 2007, 141, 355-362. [CrossRef]

17. Anikwe, M.A.N.; Eze, J.C.; Ibudialo, A.N. Influence of lime and gypsum application on soil properties and yield of cassava (Manihot esculenta Crantz.) in a degraded Ultisol in Agbani, Enugu Southeastern Nigeria. Soil Tillage Res. 2016, 158, 32-38. [CrossRef]

18. Moura, E.G.; Sena, V.G.L.; Sousa, C.C.M.; Silva, F.R.; Coelho, M.J.A.; Macedo, V.R.A.; Aguiar, A.C.F. Enhancement of the rootability of a structurally fragile tropical soil using gypsum and leguminous residues to increase the maize yield. Soil Use Manag. 2016, 32, 118-126. [CrossRef]

19. Wuddivira, M.N.; Camps-Roach, G. Effects of organic matter and calcium on soil structural stability. Eur. J. Soil Sci. 2007, 58, 722-727. [CrossRef]

20. Whittinghill, K.; Hobbie, A.; Sarah, E. Effects of $\mathrm{pH}$ and calcium on soil organic matter dynamics in Alaskan tundra. Biogeochemistry 2012, 111, 569-581. [CrossRef]

21. CPTEC/INPE. Center for Weather Forecasting and Climate Research. 2016. Available online: http://www. cptec.inpe.br/home/in (accessed on 13 May 2016). 
22. Moura, E.G.; Moura, N.G.; Marques, E.S.; Pinheiro, K.M.; Costa Sobrinho, J.R.S.; Aguiar, A.C.F. Evaluating chemical and physical quality indicators for a structurally fragile tropical soil. Soil Use Manag. 2009, 25, 368-375. [CrossRef]

23. Soil Survey Staff. Keys to Soil Taxonomy, 12th ed.; USDA-Natural Resources Conservation Service: Washington, DC, USA, 2012.

24. Aguiar, A.C.F.; Bicudo, S.J.; Costa Sobrinho, J.R.S.; Martins, A.L.S.; Coelho, K.P.; Moura, E.G. Nutrient recycling and physical indicators of an alley cropping system in a sandy loam soil in the Pre-Amazon region of Brazil. Nutr. Cycl. Agroecosyst. 2010, 86, 189-198. [CrossRef]

25. Raij, B.; Quaggio, J.A.; Silva, N.M. Extraction of phosphorus, potassium, calcium, and magnesium from soils by an ion exchange resin procedure. Commun. Soil Sci. Plant Anal. 1986, 17, 547-566. [CrossRef]

26. Heckman, J.R. Soil fertility test interpretation: Phosphorus, potassium, magnesium and calcium. In Fact Sheet FS719, Rutgers Cooperative Extension, New Jersey Agricultural Experimental Extension; 2006; Available online: file: / / C:/Users/User/Downloads/fs719.pdf (accessed on 24 March 2018).

27. Tiessen, H.; Moir, J.O. Total and organic carbon. In Soil Sampling and Methods of Analysis; Carter, M.E., Ed.; Lewis Publishers: Ann Arbor, MI, USA, 1993; pp. 187-200.

28. Hazelton, P.; Murphy, B. Interpreting Soil Test Results. What Do All the Numbers Mean? CSIRO Publishing: Clayton, Australia, 2007.

29. Montgomery, E.G. Correlation studies of corn. Annu. Rep. 1911, 24, 108-159.

30. Cottenie, A. Soil and Plant Testing as a Basis of Fertilizer Recommendations; FAO Soil Bulletin: Rome, Italy, 1980.

31. Kolahchi, Z.; Jalali, M. Effect of water quality on the leaching of potassium from sandy soil. J. Arid. Environ. 2007, 68, 624-639. [CrossRef]

32. Moore, T.R.; Turunen, J. Carbon accumulation and storage in mineral subsoil beneath peat. Soil Sci. Soc. Am. J. 2004, 68, 690-696. [CrossRef]

33. Oste, L.A.; Temminghoff, E.J.M.; Van Riemsdijk, W.H. Solid solution partitioning of organic matter in soils as influenced by an increase in pH or Ca concentration. Environ. Sci. Technol. 2002, 36, 208-214. [CrossRef] [PubMed]

34. Shepherd, M.A.; Harrison, R.; Webb, J. Managing soil organic matter-implications for structure on organic farms. Soil Use Manag. 2002, 18, 284-292. [CrossRef]

35. Mbah, E.U.; Eke-Okoro, O. Relationship between some growth parameters, dry matter content and yield of some sweet potato genotypes grown under rainfed weathered ultisols in the humid tropics. J. Agron. 2015, 14, 121-129. [CrossRef]

36. Sadras, V.O.; Milroy, S.P. Soil-Water thresholds for the responses of leaf expansion and gas exchange: A review. Field Crop. Res. 1996, 47, 253-266. [CrossRef]

37. Sivasankar, S.; Rothstein, S.; Oaks, A. Regulation of the accumulation and reduction of nitrate by nitrogen and carbon metabolites in maize seedlings. Plant Physiol. 1997, 114, 583-589. [CrossRef] [PubMed]

38. Garnett, T.; Conn, V.; Kaiser, B.N. Root based approaches to improving nitrogen use efficiency in plants. Plant Cell Environ. 2009, 32, 1272-1283. [CrossRef] [PubMed]

39. Masclaux-Daubresse, C.; Daniel-Vedel, F.; Dechorgnat, J.; Chardon, F.; Gaufichon, L. Nitrogen uptake, assimilation and remobilization in plants: Challenges for sustainable and productive agriculture. Ann. Bot. 2010, 105, 1141-1157. [CrossRef] [PubMed]

40. Borrel, A.K.; Hammer, G.L.; Henzell, R.G. Does maintaining green leaf area in sorghum improve yield under drought? II. Dry matter production and yield. Crop Sci. 2000, 40, 1037-1048. [CrossRef]

(C) 2018 by the authors. Licensee MDPI, Basel, Switzerland. This article is an open access article distributed under the terms and conditions of the Creative Commons Attribution (CC BY) license (http://creativecommons.org/licenses/by/4.0/). 